\section{Geology of Malaya}

The Geology of Malaya. By J. B. Scrivenor. Published with the Authority of the Federated Malay States Government. Pp. $\mathrm{xx}+217$. (London : Macmillan and Co., Ltd., 1931.) 16s. net.

READERS of Mr. Scrivenor's book on "The 1 Geology of Malayan Ore-Deposits" will welcome this companion volume on the geology of the fascinating and enigmatic land which has claimed the author's attention since 1903. In the introduction, an interesting and instructive account is given of the history of geological investigations in Malaya, including a brief account of the Kinta tinfield controversy. It is justly pointed out that the Kinta valley does not provide a key to the geology of the country, and that while debate has been focused on that small and intricate area, the Survey Department has been occupied with the whole of Malaya. Progress has now reached the stage where linking up with the Netherlands Indies, Indo-China, and Lower Burma has become practicable. In all these lands closely accordant results have been achieved.

After a general statement of the leading geological and geographical features of the Peninsula, there are chapters dealing with the late Palæozoic and Triassic sediments and the associated Pahang Volcanic Series. During this long period, the site of Malaya was a sea of moderate depth which was finally silted up by sediment from the east. Great crustal movements occurred later and led to great intrusions of granite, which are responsible for the valuable tin deposits of the country.

An important chapter is devoted to the granite and the associated igneous rocks. A post-Triassic age now appears to be well established, and although there are no Cretaceous sediments in Malaya, the evidence from adjoining countries suggests that the intrusions may be of late Cretaceous age. The postgranitic rocks include Tertiary coal measures; highlevel alluvium which appears to be Pleistocene or older; and recent alluvium and pumiceous ash.

The remaining chapters deal successively with weathering and laterite; metamorphism, with special reference to a puzzling series of tourmalinecorundum rocks, thought provisionally to be altered bauxite; various minerals and tektites; and materials of economic interest other than ores. The book concludes with a bibliography complete to 1930 and a good index. A noteworthy feature is a colour-printed geological map of Malaya, on the scale of 12 miles to the inch, which is folded in a pocket at the end of the volume.
The book is written throughout in a clear and pleasant style, enlivened with flashes of humour and local colour. Mr. Scrivenor is to be warmly congratulated on having made available in so acceptable a form the conclusions he has reached after more than a quarter of a century's arduous work in a tantalising land that has become notorious for the difficulty of its geological problems.

\section{Physics in the Making}

Recent Advances in Physics (Non-Atomic). By Prof. F. H. Newman. Pp. ix +378 . (London: J. and A. Churchill, 1932.) $15 s$.

$\mathrm{H}^{\text {RANKLY, we find the title of Prof. Newman's }}$ new book a little puzzling. He sets out to deal with recent advances in non-atomic physics, and, knowing his flair for exposition, we looked forward to a readable account, with due emphasis given to the experimental side, of recent developments in what we might call macroscopic or molar physics. His account is readable enough, and interesting experimental detail bulks largely therein, but the choice of topics bears singularly small relation to the title. Wave mechanics; statistical mechanics; electromagnetic radiation, including a discussion of infra-red spectra; $\gamma$-rays, cosmic rays, and the scattering and diffraction of X-rays ; ninety pages on modern magnetics, and, under the heading electricity, a discussion, inter alia, of electrolytic conduction and of super-conductivity. These be strange themes to meet in a work where we had. hoped a comfortable certainty would reign supreme and electron waves would cease to surge and roar.

The balance is to some extent redressed by a chapter on sound, which includes discussions on architectural acousties, on sound-ranging, filters, and ultra-sonics, another chapter dealing with low temperatures and their measurement, and sections treating of high pressure researches and of atmospheric electricity. Nay, with a little twisting of the terms of reference, we may even include such topics as liquid viscosity and surface tensions, certain aspects of which Prof. Newman discusses in fairly full detail.

Truth to tell, it is impossible to make a division of topics which shall be strictly logical and shall avoid serious overlap. Prof. Newman points out, perhaps a trifle optimistically, that "the whole trend of modern science is, as it should be, towards correlation ". Nevertheless, we may make a very convenient, if rough division, into molar physics, atomic physics-where the concept of the billiardball atom still subserves a useful purpose-and 